\title{
Earnings management and the role of the audit committee: an investigation of the influence of cross-listing and government officials on the audit committee
}

\begin{abstract}
This paper extends research on the corporate governance practices of transitional economies by examining whether the ability of the audit committee to constrain earnings management in Chinese firms is associated with the listing environment and the presence of government officials on the audit committee. Despite considerable regulatory reforms by the Chinese Securities Regulatory Commission (CSRC), there remain incentives for Chinese firms to manage earnings. However, government initiatives to encourage domestic firms to cross-list on the Hong Kong Stock Exchange are accompanied by improved governance. We find that the expertise and independence of the audit committee for cross-listed (CL) Chinese firms are associated with lower abnormal accruals, our measure of earnings management. Both domestic only listed firms and CL Chinese firms appoint government officials as independent members on the audit committee. However, due to the political connection between government officials and the controlling shareholder (the State), these appointments can severely mitigate audit committee independence. Subsequently, we find a significant and positive association between audit committee independence and experience and earnings management when there are government officials on the audit committee.
\end{abstract}

JEL classifications: M41, M42, M48, G34.

Keywords: Audit committee; earnings management; corporate governance; and cross-listing. 


\section{Introduction}

China is one of the fastest growing economies in the world, even though its legal and financial system is not well developed (Firth et al. 2013; He et al. 2013). Mainland China's investor protection, that is, overall creditor rights, shareholder rights, rule of law, and government corruption is among the worst in the world (Allen et al. 2005). Subsequently, over the last decade, the Chinese Securities Regulatory Commission (CSRC) published a number of regulations and recommendations on corporate governance for Chinese listed firms ${ }^{1}$. Following the regulations and recommendations issued by CSRC, there is some evidence showing that Chinese firms are actively moving towards improving corporate governance practices, such as establishing independent boards and audit committees ( $\mathrm{Li}$ et al. 2006; Cheung et al. 2008). China has made considerable attempts to improve accountability and transparency, moving from a rules-based and prescriptive accounting regime to the introduction of principles-based Chinese Accounting Standards in 2006 (Piotroski and Wong 2011).

The objective of this study is to determine whether CSRC initiatives have been successful in improving the reporting quality of Chinese firms. In this study we consider two economic reforms in China, cross-listing and fiscal decentralization, that have significantly shaped corporate governance and privatization of state-owned enterprises (SOEs). We identify cross-listing and the appointment of government officials as counteracting and moderating the efficacy of the audit committee in detecting and monitoring earnings management. Several studies have examined the effectiveness of audit committees in limiting earnings management primarily in the US context (Abbott et al. 2004; Bédard et al. 2004; Klein 2002;

\footnotetext{
${ }^{1}$ Publications include: The Code of Corporate Governance for Listed Companies in China (2001), The Recommendation for the Institution of Independent Directors in Listed Companies (2001) and The Regulations on Information Disclosure of Listed Companies (2007).
} 
Xie et al. 2003; Yang and Krishnan 2005). Research also finds that audit committees play a significant role in constraining earnings management of Hong Kong firms (Jaggi and Leung 2007). Although the role of the board (Firth et al. 2007; Lai and Tam 2007; Liu and Lu 2007) and ownership concentration (Liu and Lu 2007; Ding et al. 2007; Firth et al. 2007) are identified as important determinants of earnings management in Chinese listed firms, there is currently considerable debate about the effectiveness of the audit committee in constraining earnings management (Lin et al. 2008) ${ }^{2}$. Consequently, we set out to determine whether cross-listing or the presence of government officials on the audit committee affect the association between the audit committee and earnings management established in prior studies.

During the economic reforms in the early 1990's, the Chinese government initiated a series of agendas to improve the performance of domestic incorporated companies. One of the recommended approaches is to list domestic firms in developed overseas markets (Zhou, D.J., former chairman of the CSRC 1995). The government expects that these cross-listed firms can become world-class enterprises and compete with large multinational corporations by adopting advanced Anglo-Saxon management skills (Jia and Sun 2005).

Floating companies on a developed overseas market allows the government to generate higher privatization income. Before the 2008 global financial crisis, listing newly privatized shares on the HKEX was a common practice to raise capital. Further, the listing and governance rules of the foreign exchange may discipline management, motivating them to improve the quality of financial reporting. Conversely, this choice entails political and economic trade-offs. State ownership is diluted and voting power is decentralized as ownership becomes more diverse. By selling firms overseas, the State risks losing a powerful

\footnotetext{
${ }^{2}$ Lin et al. (2008) find that various stakeholders perceive the audit committee as a ceremonial decoration acting to lift the image of good corporate governance.
} 
tool for profit redistribution, especially as the cross-listed firms are the pillars of corporate China. Therefore, in many cases, government officials are placed on boards or committees for some political reason, even though government officials are claimed to be independent.

Another fiscal reform is the quota system of 1993-2000, which gave government officials considerable control rights and incentivised $^{3}$ them to report favourable economic performance of firms in their region (Pistor and $\mathrm{Xu}$ 2005). Although the quota system has been formally abandoned, the practice has contributed to the incentive for politically connected managers (former government officials) to restrict the flow of negative information about their firms (Piotroski et al. 2011).

The classification of government officials as independent directors is controversial due to their political connections to the controlling shareholders (the State). When the State is the major stockholder it may impose its socioeconomic objectives on the firm (Firth et al. 2012). Such preferences may cause government officials to sanction earnings management, even in the presence of cross-listing, because the marginal benefits of control are perceived by the government to exceed the marginal benefits of cross-listing. Placing a government official on the audit committee provides the opportunity for the government official to confer with the interests of the State rather than minority shareholders, which in turn can encourage earnings management. Consequently, a government official on the audit committee has both the incentive and the opportunity to endorse earnings management.

This study uses a sample of 408 observations of Chinese firms from 2004 to 2008. Two hundred and four firms are cross-listed on the HKEX (CL) and the Chinese domestic stock exchanges. We match the $204 \mathrm{CL}$ firms with firms domestically listed only (DLO). We conduct a three-step moderation regression to test the impact of cross-listing and government

\footnotetext{
${ }^{3}$ Incentives include future career advancement, delisting threats for underperformance and offering future quotas.
} 
officials on the audit committee and earnings management relationship. Our study finds that audit committee independence and experience are negatively associated with abnormal accruals, our measure of earnings management. However, this result is dependent on the firm cross-listing on the HKEX. We also find that the monitoring role of the audit committee is jeopardised when government officials are on the audit committee. Although classifying government officials as independent members satisfies the listing requirement, our results show that their appointment negates the negative association between audit committee independence and experience and abnormal accruals.

Our paper contributes to the literature in several ways. We extend the research on transitional economies by considering the effect of cross-listing and government control on audit committee effectiveness. This is an important extension as government control of listed firms is common in many transitional economies and can influence the way firms operate (Firth et al. 2012). The development of the Chinese stock market accelerated in the 1990s around the same time as other transition economies (Pistor and $\mathrm{Xu} 2005$ ) and the financing of state owned enterprises moved from the government to the market. Typically, the transition economies develop from a core of central planning and extensive state ownership. Following the push for public listing in the domestic market, firms still have high State ownership concentration, vulnerable minority investor rights, and weak public enforcement of fines and sanctions by regulators. In addition to domestic listing, cross-listing has been a major trend in transitional economies in the past twenty years, and the impact on stock markets has been dramatic. Karolyi (2010) reports that over 3,000 multinational corporations have a secondary listing on over 40 major stock exchanges, with NYSE Euronext (Europe), Deutsche Börse, Hong Kong, and Singapore all becoming popular destinations for cross-listed firms incorporated in developing countries. Dominated by firms from BRIC countries (Brazil, Russia, India, and China), capital raised by cross-listed firms totalled $\$ 16.6$ billion in 2010 
(2011 annual report of Citi Depositary Receipts Services). Therefore, our paper sheds new light on how the legal, regulatory environment and listing requirements play a role in accounting quality. The paper identifies the benefits of cross-listing into a developed market through the improved detection of earnings management which depends on the characteristics of the audit committee. Governance reforms aimed at improving the quality of financial reports are successful for Chinese firms cross-listed on the HKEX because the independence and experience of audit committee members is negatively associated with abnormal accruals. In contrast, we find a marginally positive association between audit committee independence and earnings management for domestic firms.

The study demonstrates the role of government officials and cross-listing on the relationship between audit committee's effectiveness in monitoring earnings. Government officials as independent audit committee members are more likely to be influenced by the State and they take instructions from, and act for the benefit of, these controlling shareholders ahead of the minority shareholders of the listed companies. Therefore, they are less likely to monitor or prevent earnings management or a controlling stockholder from shifting profits between the listed company and the parent company (Lo et al. 2010), even when the firm is cross-listed on a more developed market. The State, as the major controlling shareholder in many Chinese listed companies, may be the cause of poor firm efficiency (Allen et al. 2005; Firth et al. 2012) and earnings management. Finally, this study provides some evidence that the role of the audit committee needs attention in mainland China. Our investigation reveals a lack of detailed disclosures on the composition of the audit committee by domestic firms.

The implications of this study are that investors can have greater confidence in the reliability of earnings when the Chinese firm is cross-listed in Hong Kong due to greater enforcement of the stricter HKSEX regulatory framework. Consequently, Chinese regulators may consider 
mandating specific recommendations on the composition of the audit committee. Furthermore, the CSRC should consider reclassifying government officials as "not independent" due to their ties with the government. A policy implication of our research is that, when the State is the major shareholder, more "truly" independent directors are needed for monitoring earnings to ensure the reliability of the earnings figure and to increase the confidence of investors in reported earnings. Our results reveal that the efficacy of the audit committee is increased by excluding government officials from participating on the audit committee.

The remainder of the paper is structured as follows. Section 2 provides the institutional background and hypotheses development. Section 3 discusses the method used to test the hypotheses and the results are presented in section 4 with concluding comments in section 5 .

\section{Literature review and hypothesis development}

The corporate governance system adopted by Chinese listed firms is described as a control-based or administrative model (Cheung et al. 2008; Gao et al. 2008). The stock market is closely controlled by the government and controlling shareholders (generally the State) directly control listed firms. Cheung et al. (2008: 466) characterise the governance problems of China as "concentrated ownership by the state, multiple-goals of listed companies, a weak legal system, inadequate financial disclosure, expropriation of minority shareholders by controlling shareholders and short-run speculating investments". China is moving from a centrally planned economy to a market orientated economy. During this transition, the focus in China has been on the rationalisation of ownership structures and the development of a corporate governance system suitable for the Chinese institutional setting. As a transitional economy, it is particularly important for China to evoke confidence in 
reported earnings which in turn relies on reported accounting earnings accurately portraying the economic reality of the firm's financial activity (Krishnan and Parsons 2008). However, many accounting-based regulations create incentives for Chinese firms to manipulate earnings upwards. For example, IPOs must have at least two consecutive years of operating profits and securities regulations requires that applicants maintain a minimum level of return on equity for three years prior to the application (Chan et al. 2012).

Corporate governance controls are vital for monitoring managers' behaviour and providing transparent and reliable financial information to stakeholders. The audit committee is a governance control designed to oversee financial reporting, internal controls to assess risk, and auditor activity (DeZoort et al. 2002). A primary role of audit committees is to ensure the quality of corporate financial reporting which in turn is dependent on the audit committee's ability to detect earnings management (among other things).

However, research on the association between the audit committee and earnings management in China is limited to publications in the Chinese language and has produced mixed results (Liu and Ma 2008; Zheng and Liu 2008). The negative association between audit committees and earnings management may not hold in China where ownership concentration is high and minority investor rights and public enforcement of fines and sanctions by regulators are weak. Consequently, we posit that two economic reforms provide contradictory incentives and opportunities for monitoring earnings management: cross-listing and placing government officials on the audit committee. An effective audit committee fulfils its oversight role when it is independent of management, has a level of financial and industry experience to carry out its duties, and actively monitors internal controls and financial reporting (Carcello et al. 2006). 


\subsection{Cross-listing on the Hong Kong Stock Exchange}

Since the early 1990s, an increasing number of enterprises from emerging markets have actively pursued a public listing on developed stock markets, typically motivated by the desire to raise long-term capital for future growth. In addition to raising capital, listing on a developed market helps to build an international image and gain access to the global market.

Research shows that firms incorporated in developing countries and listed in developed overseas market improve their governance practices (Sun and Tobin 2005). Sun and Tobin (2005) demonstrate how the Bank of China restructured its corporate governance practices following its initial public offering in Hong Kong in 2006 by increased board independence, including non-Chinese independent directors with Western experience, and greater transparency in some sensitive areas, such as loan classification and risk management. HKEX listing requires Chinese firms to follow the rules and regulations of the Hong Kong stock market, leading to an improvement in their corporate government practices in line with the listing requirements. After cross-listing and increasing the number of foreign investors, the company's shareholders base is more diversified. Therefore, the agency costs in CL firms are more demonstrable than in DLO firms.

The agency costs of listing on a more mature market than the domestic market are not insignificant. Not only are there direct listing costs, such as fees paid to the accounting firms, the regulators and other professionals, but there are also other indirect costs, including costs of adherence to stricter rules.. In spite of the expensive cost of listing, Chinese companies still decide to list internationally. The government encouraged large state-owned enterprises' to cross-list in early periods to learn and improve their corporate governance. One of the major differences between domestically listed only (DLO) firms and cross-listing (CL) firms can be demonstrated by the formation and disclosures of the firm's audit committee. The state 
realizes that strict compliance enables the listing firms to establish an effective audit committee and enhance monitoring functionality. However, the majority of Chinese listed firms did not establish an audit committee until 2004 (Lin and Liu 2009) and research on the role of the audit committee in Chinese firms finds that audit committees have no significant effect on firm performance (Wei 2007). By 2008, although the majority of DLO firms had set up an audit committee, they did not clearly list their objectives and responsibilities while some failed to disclose the composition of the audit committee. In contrast, the Hong Kong Society of Accountants (HKSA) recommended the formation of an audit committee for Hong Kong firms in 1993 and most listed firms in HK had established an audit committee by 1997. The audit committee requirements for Hong Kong listed firms provide more detail than those of the CSRC (see Appendix A). In particular, the HKEX details the constitution requirements of the audit committee, such as size and independence. The investors in the HK market can get access to the information about the composition of an audit committee from annual reports, including the members' backgrounds and audit committee's objectives and responsibility (Jaggi and Leung 2007).

As cross-listing firms face increased commitment to follow the governance practices of the developed market, the costs are likely to be higher for these firms that have been accustomed to fewer governance controls and ineffective monitoring of earnings. The premise of this study is that the benefits associated with CL firms in Hong Kong outweigh the costs of more transparent governance practices and the subsequent reduced opportunity to manage earnings. We suggest that lower levels of earnings management of the Chinese CL firms are due to the efficacy of the audit committee, not merely the existence of an audit committee. An effective audit committee fulfils its oversight role when it is independent of management, has a level of financial and industry experience to carry out its duties, and actively monitors internal controls and financial reporting. The effectiveness of an audit committee in monitoring 
earnings management can be enhanced as CL firms are required to adhere to stricter listing rules of the mature market. This leads to the first proposition:

H1: A negative association between the audit committee efficacy and earnings management depends on Chinese firms cross-listing on the HKEX.

\section{3 Government officials}

The predictions of agency theory apply in public corporations when owners assign the daily operating power to managers, giving rise to concerns that managers may not act in the best interests of the owners. The underlying assumption of the principal-agent perspective is that all principals are homogenous in their aim of maximizing returns on investments. Such an assumption holds in the institutional setting of developed economics, where the institutional and minority investors have a primary goal for profit maximization. Once their goals diverge, the assumptions of the theory change. In China, the goals of principals are different and the controlling principal may expropriate minority shareholders' funds due to the lack of legal protection. Many controlling shareholders directly participate in management and appoint their representatives to the board (Claessens et al. 2002).

In China, it is common that firms appoint retired or acting government officials to the boards and classify them as independent directors ${ }^{4}$. However, the classification of government officials as independent is controversial. First, government officials may have political connections to the State or the controlling shareholders. Chen et al. (2008) find that some local governments nominate their representative on committees as independent members, which facilitates earnings management for political motives. Fan et al. (2007) find that politically connected CEOs in publicly listed companies in China are likely to influence

\footnotetext{
4 According to Section 3, Recommendation for establishment of independent director system in Chinese listed firms ' (CSRC, 2001),
} 
board structure such that their boards are likely to be populated by current or former government bureaucrats and have fewer directors with relevant professional backgrounds. The fiscal decentralization reform in the 1990's encouraged local governments to compete with each other for funding in order to develop local economies without supplemental local public spending (Sun and Tobin 2005). In doing so, the local government obtains the benefits of new capital investment and economic growth from a successful cross-listing (Sun and Tobin 2005). Therefore, the local government is aligned with the firms with a common interest in raising more capital from the stock market.

Delisting represents a loss to the region ${ }^{5}$ while government officials also lose face and potential promotion opportunities (Chan et al. 2012). Chan et al. (2012: 51) cite research that finds local government controlled entities often help their listed subsidiaries to boost earnings or avoid losses through related party transactions, asset and equity sales and purchases, fiscal subsidies, and restructuring. Subsequently, the threat of delisting can motivate government officials to curb negative information about the firm. Because of these complicated interconnections, the "independent" government officials may act in the interests of the local government who at the same time is the dominant controlling shareholder (Sun and Tobin 2005). Thus, government officials have incentives to serve the controlling shareholder interests, those of the State or local government, rather than the interests of the minority shareholders. Hence, the perceived and actual independence of the audit committee is compromised.

Second, government officials may lack the necessary financial, accounting, and industry experience to monitor managers (Fan et al. 2007). They may have a successful political career and know how to deal with complicated relationships among different groups, but they may not have the related business background. Research also shows that senior management

\footnotetext{
${ }^{5}$ The region loses the means to fund economic growth and the firm loses future rent-seeking opportunities
} 
in Chinese listed firms maintain close political relationships with the monitoring agent, the State (Xu et al. 2005). They also find that some middle-level management officials are directly transferred from positions as government officials with no professional corporate background. Therefore, the monitoring power of the independent audit committee is reduced in the presence of government officials on the audit committee.

As the government official's alliance is with the State or the controlling shareholders, these firms experience greater information asymmetry. The addition of government officials onto the audit committee to monitor earnings management will be compromised if the State places government officials on boards and committees to counteract the loss of control from cross-listing and privatization. Consequently, government officials on the audit committee have the incentive and opportunity to portray the earnings according to the State's political objectives. Therefore, we expect a change in the efficacy of the audit committee in monitoring earnings management when there is a government official on the audit committee. Consequently, the following hypothesis is developed:

$\mathrm{H} 2$ : The negative association between audit committee efficacy and abnormal accruals is moderated by the presence of government officials on the audit committee.

\section{Research method}

\subsection{Sample selection and data source}

Cross-listing refers to situations where firms list their shares on one or more foreign stock exchanges in addition to a domestic exchange. This research uses a sample of 408 firm-year observation from 2004 to 2008. First, we collect 210 observations of Chinese firms cross-listed on the HKEX from 2004 to $2008^{6}$. Many Chinese domestically listed firms only

\footnotetext{
6 As of June 182009 there are 470 Chinese mainland firms listed on the HKEX (http://english.peopledaily.com.cn/90001/90778/90857/6681729.html)
} 
formed audit committees and started to disclose audit committee information since 2004. As well, the Chinese government dramatically slowed down the cross-listing process in HK after the 2008 financial crisis. Therefore, the sample for analysis includes the years from 2004-2008. We began our sample collection using the top 100 Chinese firms cross-listed on the $\mathrm{HKEX}^{7}$ for 2007. After dropping firms from the banking sector, we have a sample size of 93 firm-year observation for 2007 for a pilot study. We then collected additional observations from 2004 to 2008 to increase the sample size to 210 . The selection for the additional 107 observations is random. Two CL firms with extreme values of abnormal accruals $(A B A C)$ and four CL firms without audit committee's information were deleted, leaving a sample size of 204 observations for $94 \mathrm{CL}$ firms for the analysis ${ }^{8}$.

To test the premise of this study that there are benefits for Chinese firms listing in Hong Kong, we matched the sample of 204 HKEX cross-listed Chinese firm observations with 204 Chinese firm observations listed only on the Shanghai or Shenzhen stock exchanges (mainland-listed firms). We use three criteria for matching the sample with mainland firms. The mainland-listed firms are matched with the Hong Kong cross-listed firms based on the same industry code (GICS classification), the same year of collection and, finally, firm size using total assets, as the basis for comparison. Specifically, we sort total assets in each industry in each year and match the mainland firms with Hong Kong cross-listed firms in the industry and in the data collection year with the closest asset value (Jog et al. 2010). Finally, we have a sample of 408 firm year observation consisting of 204 from cross-listing and 204 from domestically listing only.

\footnotetext{
7 The Top 100 are classified according to market capitalisation in Hong Kong dollars.

${ }^{8}$ A silhouette measure of cohesion and separation was performed on the matching variables of industry, year and total assets of the two samples. The silhouette coefficient, which is a measure of both cohesion and separation, is close to the maximum value of 1 (near 90 percent), which means the within-cluster distances are small and the between-cluster distances are large.
} 
The audit committee data is hand collected from the firm's annual financial reports while the financial data is collected from the WIND database for the firms listed in Mainland China and the Mintglobal database for the firms listed on the HKEX.

\subsection{Dependent variable}

Abnormal accruals can be manipulated by management by using professional judgment in their accounting choices. Therefore, abnormal accruals models are often used as a proxy for earnings management in the literature and we use the modified Jones model (Jones 1991) from Butler et al. (2004) as a proxy for earnings management. We also use variations of this model in testing the robustness of our results.

$\mathrm{TA}_{\mathrm{it}} / \mathrm{AT}_{\mathrm{it}}=\alpha_{0}+\alpha_{1}\left(\Delta \mathrm{Rev}_{\mathrm{it}} / \mathrm{AT}_{\mathrm{it}}\right)+\alpha_{2}\left(\mathrm{PPE}_{\mathrm{it}} / \mathrm{AT}_{\mathrm{it}}\right)+\varepsilon$

Where: $\mathrm{TA}_{\mathrm{it}}$ is total accruals calculated by adding earnings before extraordinary items and discontinued operations minus operating cash flows from continuing operations and then dividing by total assets at the beginning of the year. $\mathrm{AT}_{\mathrm{it}}$ is the total assets for firm $i$ in the year $t . \Delta \operatorname{Rev}_{\text {it }}$ is the change in revenue firm $i$ in the year $t . \quad \mathrm{PPE}_{\mathrm{it}}$ is net property, plant and equipment firm $i$ in year $t$. Total accruals are separated into expected accruals and abnormal accruals.

\subsection{Independent variables}

\subsubsection{Cross-listing}

We identify Chinese firms that are cross-listed on the Hong Kong Stock Exchange by examining their listing status on the www.hkex.com website. Leading Chinese firms have listed on the Hong Kong Stock Exchange (HKEX) since 1993 and nearly 25\% of HKEX initial public offerings in the last ten years were Chinese firms (Chi and Zhang 2010). The cross-listed firms are incorporated in Mainland China and approved by the China Securities. HKEX listing requires Chinese firms to follow the rules and regulations of the Hong Kong 
stock market, leading to an improvement in their corporate government practices in line with the listing requirements. The audit committee requirements for Hong Kong listed firms provide more detail than those of the CSRC (see Appendix A). In particular, the HKEX details the constitution requirements of the audit committee, such as size and independence. We suggest a negative coefficient from the interaction of AC efficacy and earnings management of the Chinese CL firms. This result is expected due to the audit committee following the HKEX requirements.

\subsubsection{Government officials}

To determine committee member characteristics we analyze their biography in the firm's financial reports or searched for their curriculum vitae $(\mathrm{CV})$ on the internet. Each audit committee member voluntarily provides a $\mathrm{CV}$ to the shareholders following their nomination from the board. If a member has past experience working in a government department serving as a public servant, they are classified as a government official. In many cases, the government officials are either retired or not incumbent when they commence their position on the committee. We also use this method to determine committee members' independence, expertise and work experience.

According to Section 3, Recommendation for establishment of independent director system in Chinese listed firms (CSRC 2001), government officials met the requirements for an independent director. There is a theoretical argument that an audit committee with government officials will provide a company with a high level of access to various resources, particularly through their political connections. However, the independence role of government officials is controversial as they may act in the interests of the government, or may lack the necessary financial, accounting, and industry experience to monitor managers (Fan et al. 2007). They can have a successful political career and know how to deal with 
complicated relationships among different groups, but they may not have the related business background to detect earnings management. Therefore, we expect that the efficacy of the audit committee will be compromised in firms when there are government officials on the audit committee. We predict the coefficient for the interaction of $\mathrm{AC}$ efficacy and earnings management is positive in the presence of government officials on the AC. This result is expected due to the audit committee following the State's interests rather than minority shareholders' interests.

\subsubsection{Audit committee efficacy}

An effective audit committee fulfils its oversight role when it is independent of management, has a level of financial and industry experience to carry out its duties, and actively monitors internal controls and financial reporting (Carcello et al. 2006). Subsequently, this paper evaluates audit committee effectiveness from the perspective of the non-negotiable characteristic of independence and the experience that independent members bring to the committee.

Agency theory posits that outside members facilitate effective monitoring because they are independent of management and have reputational incentives to signal to the labour market that they are experts in decision control (Fama and Jensen 1983). The CSRC suggests that firms may voluntarily establish an audit committee with a majority of independent directors. The HKEX requires firms to have an audit committee that consists of at least five independent non-executive directors (see Appendix A). The rationale is that independent audit committee members are more likely to be free from management's influence, which ensures that financial information is conveyed to shareholders in an objective way. Thus there is less opportunity for earnings management. 
In a transitional economy, such as China, it is even more important for independent audit committee members to contribute to monitoring the earnings figure by having accounting, financial and industry experience. United States research supports the notion that these factors are important for constraining earnings management (e.g. Bédard et al. 2004; Dhaliwal et al. 2006; Xie et al. 2003). In this paper, it is anticipated that including independent directors on the audit committee with financial and industry experience is associated with the committees' ability to detect earnings management and complements the monitoring role of the independent audit committee.

Following preliminary analysis, we use principal component factor analysis to comprise a factor score for audit committee directors' experience. A factor score of independent audit committee members' accounting, financial and industry experience is created by using principal components' factor analysis. The three components collected from the information provided in the firm's annual reports are: the number of independent audit committee directors with accounting experience divided by the number of directors on the audit committee; the number of independent audit committee directors with financial experience divided by the number of directors on the audit committee; the number of independent audit committee directors with industry experience divided by the number of directors on the audit committee. Typically, research has only used one of these variables to measure expertise (e.g. Carcello et al. 2006; Dhaliwal et al. 2006; Lin et al. 2006). Subsequently, we used a factor score of these measures to test the combined influence of independent audit committee directors' experience.

\subsection{Control variables}

In addition to the experimental variables, we use prior research to identify and control for other factors that are likely to motivate or constrain managers' incentives to manipulate 
earnings. A distinctive characteristic of Chinese listed firms is State ownership concentration with approximately two-thirds of issued shares held directly or indirectly by the State. Research examining the association between State-owned shareholdings and earnings management is limited and has produced conflicting research findings. For example, Firth et al. (2007) find that State-ownership concentration is only marginally positively associated with discretionary accruals (at the 10 percent level) while Ding et al (2007) find a non-linear association; at lower levels of State-ownership there is a positive association with earnings management and a negative association at higher levels of ownership. Consequently we do not predict a direction for the association between state ownership and earnings management.

To achieve specific ROE targets and/or avoid losses, Chinese firms may manipulate earnings to achieve ROE targets. Consequently, a disproportionate number of Chinese firms report ROE realizations around the CSRC's historical performance benchmarks of zero, six and ten percent 2006 (Piotroski and Wong 2011). We expect that this is the case for both the domestic and cross-listed Chinese firms. To control for these effects we create a dummy variable ROEDUM representing ROE less than zero and predict that the coefficient of ROEDUM will be positively associated with $A B A C$.

Big 4 auditors (Big4): Research on the association between Big 4 auditors and earnings management show that firms audited by the Big 4 have lower levels of earnings management, implying that Big 4 auditors help to constrain earnings management (Becker et al. 1998; Krishnan 2003). We expect a negative association between Big 4 and abnormal accruals. Leverage (LEV): A firm's leverage ratio influences both risk management and accrual management (Smith and Stulz 1985). Managers may manage earnings to avoid debt covenant violations (DeFond and Jiambalvo 1994; Sweeney 1994). Alternatively, firms with high levels of debt may be close to violation of debt covenants, and are typically subject to 
closer monitoring by creditors, which reduces agency costs. Hutchinson and Leung (2007) argue that higher levels of debt may place the firms under greater lender scrutiny. Subsequently we predict a negative association with abnormal accruals.

Market-to-book ratio (MBVA): It is easier for fast growing firms to engage in earnings manipulation than it is for mature firms since it is difficult to observe the business activities of fast growing firms. Further, firms growing rapidly may have internal control problems (Kinney and McDaniel 1989). Companies with high growth rates may have problems operating efficient audit committees and this might exacerbate the practice of earnings management. Firm size (LNAT): Smith and Watts (1992) suggest that firm size is positively related to various types of corporate governance controls such as debt covenants, dividend policy, and management compensation. We expect less manipulation of earnings in larger firms as they are more likely to have greater analyst following and consequently are under greater scrutiny. Different types of industries may have different opportunities and incentives to manipulate earnings so we control for industry (INDUSTRY) using dummy variables. Finally, YEAR is included in the model as the economic conditions in a particular year are likely to be associated with the motivation to manipulate earnings.

\subsection{Model}

Hypotheses 1 and 2 are formally investigated using random effects generalised least square (GLS) regression estimated with clustered-robust (also referred to as Huber-White) standard errors to control for any serial dependence in the data (Gow et al. 2010; Petersen 2009). The results of the Hausman test determine that a random effect GLS regression model is appropriate to test the panel data. While testing the first and second hypotheses we control for the potential problem of selection bias and endogeneity with the two-stage Heckman (1976) procedure. We first compute the Inverse Mills Ratio (MILLS) (Heckman 1976; DiNardo and 
Johnston 1997) from the model that predicts the factors that are associated with dual listing, that is, firms with lower abnormal accruals $(A B A C)$ may choose to cross-list. We then use the MILLS as an additional control variable in the stage 2 model to determine the association between $A B A C$ and audit committee efficacy. In addition, random effects generalised least square (GLS) regression estimated with clustered-robust (also referred to as Huber-White) standard errors is used in the second stage of the analysis to control for any serial dependence in the data (Gow et al. 2010; Petersen 2009).

Stage 1

Probit model

$\mathrm{HKCL}=\alpha_{0}+\alpha_{1} \mathrm{ABAC}+\alpha_{2} \mathrm{YEAR}+\alpha_{3} \mathrm{INDUSTRY}+\alpha_{4} \mathrm{ROE}_{t}+e$

Stage 2

Model (3) tests whether the association between the audit committee efficacy and earnings management depends on Chinese firms cross-listing on the HKEX.

$\mathrm{ABAC}=\alpha_{0}+\alpha_{1} \mathrm{HKCL}+\alpha_{2} \mathrm{ACIND}+\alpha_{3} \mathrm{ACEXP}+\alpha_{4} \mathrm{HKCL} * \mathrm{ACIND}+\alpha_{5} \mathrm{HKCL} * \mathrm{ACEXP}+$ $\alpha_{6}$ MILLS $+\alpha_{7}$ STATE $+\alpha_{8}$ BIG $4+\alpha_{9}$ LEV $+\alpha_{10}$ ROEDUM $+\alpha_{11}$ MBVA $+\alpha_{12}$ LNAT $+\alpha_{13}$ YEAR + $\alpha_{14} \mathrm{INDUSTRY}+e$

Model (4) tests whether the association between audit committee efficacy and abnormal accruals is moderated by government officials on the audit committee. Dummy variables were used to test the interactions.

$\mathrm{ABAC}=\alpha_{0}+\alpha_{1} \mathrm{GOV}+\alpha_{2} \mathrm{ACIND}+\alpha_{3} \mathrm{ACEXP}+\alpha_{4} \mathrm{GOV} * \mathrm{ACIND}+\alpha_{5} \mathrm{GOV} * \mathrm{ACEXP}+\alpha_{6} \mathrm{MILLS}+$ $\alpha_{7} \mathrm{STATE}+\alpha_{8} \mathrm{BIG} 4+\alpha_{9} \mathrm{LEV}+\alpha_{10} \mathrm{ROEDUM}+\alpha_{11} \mathrm{MBVA}+\alpha_{12} \mathrm{LNAT}+\alpha_{13} \mathrm{YEAR}+\alpha_{14} \mathrm{INDUSTRY}$ $+e$

A description of these variables can be found in Table 1 . 


\section{Empirical analysis and the results}

\subsection{Descriptive statistics and bivariate analysis}

Details on industry collection patterns are reported in Table 2. More than seventy-five percent of the sample is in the material and industrial sector.

\section{Insert Table 2 about here}

Table 3 reports the descriptive statistics and the results of a paired-sample $t$-test, which examines the difference between CL and DLO firms. Fifty-one percent of the HKCL sample and 43 percent of the DLO sample have at least one government official on the audit committee, which shows the popularity of government officials being chosen as an agent for the controlling shareholders and providing political links and resources. The results show that State-controlling ownership (STATE) average percentage is 49 percent of issued shares for $\mathrm{CL}$ and DL firms. Although considerable care is taken in matching the sampled firms, there still remain some significant differences between the CL and DLO Chinese sample. As expected, we find that the absolute accruals of DLO sample are significantly higher than those of the CL sample (13.5 percent and 10.8 percent respectively). While 99 percent of CL firms have an audit committee only 72 percent of the DLO firms have established an audit committee. Audit committees in CL firms are more independent and have a higher level of expertise than those in DLO firms.

\section{Insert Table 3 about here}

The Pearson's Correlation Matrix presented in Table 4 demonstrates a negative association between $A B A C$ and whether the Chinese firm is cross-listed on the HKEX, thus providing preliminary support for the notion that there are benefits for cross-listed firms in the form of 
lower earnings management. In addition, $G O V$ and $A B A C$ are positively correlated at the $10 \%$ significance level.

Insert Table 4 about here

\subsection{Multivariate analysis}

\subsubsection{Results of testing Hypothesis 1: Cross-listing}

The results of the regression analysis for the main hypotheses are reported in Tables 5 and 6 . First, we test whether the existence of the audit committee is associated with lower earnings management for the full sample of Chinese firms and find no significant association. There are three steps followed for testing H1. Table 5 shows that there is no significant association between the existence of an audit committee and $A B A C$ (our measure of earnings management) for the full sample. The results in Panel A show a marginally significant negative association between $A B A C$ and whether Chinese firms are cross-listed on the HKEX, suggesting that there are benefits in cross-listing in the form of lower earnings management ${ }^{9}$.

Second, we test whether audit committee efficacy, as measured by ACIND and ACEXP, is significantly related to $A B A C$. We find a negative association between $A B A C$ and $A C I N D$ and $A C E X P$ (at $p<0.10 ; p<0.05$ respectively) which suggests that merely establishing an audit committee is not associated with lower earnings management, but that an effective audit committee is. Next we determine whether that association between audit committee efficacy and $A B A C$ is dependent on Chinese firms' regulatory environment, that is, cross-listing. We formally test $\mathrm{H} 1$ by interacting $H K C L$ and audit efficacy on $A B A C$. While controlling for the possibility of selection bias by including the MILLS ratio, the results reported in Panel C

\footnotetext{
9 Tests for multicollinearity are run simultaneously with each regression. Variance inflation factors are within acceptable levels in all cases $(<2)$ and are subsequently not reported in the Tables.
} 
show that after the addition of interaction variables, there is a negative relationship between $H K C L * A C I N D$ and $A B A C(\beta=-0.082, p<0.10)$ and $H K C L * A C E X P(\beta=-0.161, p<0.05)$. The results suggest that the audit committee's efficacy in monitoring earnings management depends on the more stringent rules of the HKEX. The MILLS ratio is used to control for potential selection bias that might arise in our sample. It is observed that the estimated coefficients on the inverse Mill's ratio are not statistically significant, suggesting that selection bias does not have an important effect on our findings (Lennox et al. 2012).

$L E V$ and $B I G 4$ are negatively and significantly associated with abnormal accruals as expected ( $\beta=-0.075, p<0.05 ; \beta=-0.362, p<0.01$ respectively). The variables, ROEDUM and STATE are positively associated with abnormal accruals $(\beta=0.017, p<0.05 ; \beta=0.165, p<$ 0.05 respectively). This result suggests greater incentives for managers of loss firms and firms with high State ownership to manipulate earnings. These results are supportive for H1. Taken together, our results support the proposition of agency theory that the monitoring role of the audit committee is important in constraining opportunistic earnings management but that relationship depends on Chinese firms cross-listing on the Hong Kong Stock Exchange.

Insert Table 5 about here

\subsubsection{Results of testing Hypothesis 2: Government officials}

Table 6 reports the results of testing H2; whether the association between the audit committee and abnormal accruals is moderated by the role of government officials. First, we test the association between government officials on the audit committee of DLO firms. In Panel A we find a significant and positive association between a government official on the audit 
committee and abnormal accruals $(\beta=0.035, p<0.10)$. Abnormal accruals are negatively associated with audit committee independence for DLO firms $(\beta=-0.219, p<0.10)$. Next, we test the association between a government official on the audit committee and abnormal accruals for CL firms and report the results in Panel B. There is a positive association between a government official on the audit committee and abnormal accruals $(\beta=0.031, p<$ 0.10) and a negative association between audit committee independence and expertise and $A B A C(\beta=-0.109, p<0.05 ; \beta=-0.162, p<0.05$ respectively $)$.

Panels $\mathrm{C}$ and $\mathrm{D}$ report the two-way interaction between $G O V$ and audit committee effectiveness for DLO and CL firms separately to determine whether cross-listing Chinese firms on the HKEX diminishes the effect of government officials on earnings management. The coefficient for the interaction between audit committee efficacy and the presence of a government official on earnings management is positive for both DLO and CL firms. Particularly, there is a positive relationship between $G O V^{*} A C I N D$ and $A B A C(\beta=0.245, p<$ $0.05)$ and $G O V^{*} A C E X P$ and $A B A C(\beta=0.282, p<0.01)$ for DLO firms and $G O V^{*} A C I N D$ and $A B A C(\beta=0.045, p<0.10)$ and $G O V^{*} A C E X P$ and $A B A C(\beta=0.266, p<0.01)$ for $\mathrm{CL}$ firms.

The results reveal that due to the China-specific agency conflict of government intervention through government officials on the audit committee, even cross-listing on the stricter HKEX with expert independent directors on the audit committee, does not deter earnings management. The supervisory role of the Government's official is compromised by incentives for them to serve the controlling shareholder interests, the State, rather than the interests of the minority shareholders. ${ }^{10}$ However, this proposition is entirely subjective and

\footnotetext{
${ }^{10} \mathrm{We}$ also run the analysis using the proportion of government officials to independent audit committee directors and find the results remain the same.
} 
requires further investigation. The results should be interpreted with caution given the lack of detailed DLO disclosures on audit committee characteristics.

Insert Table 6 about here

\subsection{Sensitivity analysis}

\section{Income-increasing and income-decreasing accruals}

Obviously the audit committee is concerned about earnings management in total but is also worried about the extent management uses accruals to increase or decrease earnings. Consequently, we categorise abnormal accruals as income-increasing (IBBC) and income-decreasing abnormal accruals $(D B B C)$ and report the results in Table 7. A plus sign represents income-increasing or upwards earnings management ${ }^{11}$, while a negative sign signifies income-decreasing or downwards ${ }^{12}$ earnings management (Healey and Wahlen 1999; Bartov et al. 2000).

The three-step moderating regression for re-testing $\mathrm{H} 1 \mathrm{using} I B B C$ and $D B B C$ as dependent variables generates results that provide evidence supporting $A B A C$ results. The third step in our main test (see Table 5) shows a negative association between $H K C L * A C I N D$, and $H K C L * A C E X P$. When using the dependent variable $I B B C$ or $D B B C$, the negative association is only significant for $H K C L^{*} A C I N D(\beta=-1.5190, p<0.10 ; \beta=-0.153, p<0.10)$. These results are consistent with the reported results using $A B A C$ as the dependent variable and add validity to the previously reported results.

\section{Insert Table 7 about here}

\footnotetext{
11 A firm choosing aggressive accounting choices may accelerate revenue recognition or delay expense recognition. Using these aggressive accounting techniques can lead to income-increasing accruals.

12 A firm selecting conservative accounting choices may postpone revenue recognition or speed up expense recognition and this can result in income-decreasing accruals.
} 


\section{Summary, conclusions and limitations}

China has outperformed other transition economies in terms of liquidity and ability to raise funds (Pistor and $\mathrm{Xu}$ 2005). This could be due to many factors. In this study we consider two factors, cross listing and the influence of government officials. This paper extends the research on the corporate governance practices of transitional economies by examining how cross-listing and government officials can impact the relationship between audit committees and earnings management.

Although the Chinese Securities Regulatory Commission (CSRC) has initiated regulatory governance reforms for Chinese listed firms aimed at improving the quality of financial reports, our results suggest that the reforms have not been entirely successful. We find that initiatives that encourage cross-listing of Chinese firms are successful in improving financial reporting as we find that the independence and experience of audit committee members is negatively associated with abnormal accruals. In contrast, we find a marginally positive association between audit committee independence and earnings management for DLO firms. When an "independent" government official is on the audit committee, the benefits of cross-listing and audit committee efficacy are compromised as we find that the interaction of government officials and audit committee efficacy is positively associated with earnings management. While the initiatives that encourage cross-listing have been successful in improving financial reporting, including government officials as independent directors has a detrimental effect on financial reporting quality. Previous research suggests that a government's reluctance to relinquish its property rights in firms can have significantly negative consequences on corporate governance (Fan et al. 2007). Our results suggest that governments place officials on boards and committees to counteract the loss of control from cross-listing and privatization. 
A limitation of this study is that the results of a single-country study are specific to that country's conditions. However, the evidence from China can be useful to other transitional countries that have weak legal systems and weak property rights protection.

The interest in Chinese stocks is driven by the strong growth of the Chinese economy and the potential to develop further in the future. Consequently, the results of this study have implications for investors wishing to invest in Chinese firms because they can have greater confidence in the reliability of earnings when the firm is cross-listed in Hong Kong. Firms that comply with the HKSEX regulatory framework have more reliable financial reporting and stricter governance controls than DLO firms. Consequently, Chinese regulators may benefit from the findings in this research by mandating specific recommendations on the composition of the audit committee. In particular, this study raises the question of whether government officials are truly independent. The efficacy of the audit committee is increased by excluding government officials from participating in the $\mathrm{AC}$ and the incentives and opportunities to opportunistically manage earnings are reduced. Our investigation also revealed a lack of detailed disclosures on the composition of the audit committee by DLO firms, another issue to be considered by the CSRC.

A recent report from KPMG China (2013) states that the audit committee should stay focused on financial accounting and reporting ${ }^{13}$ and "Audit committees will face a host of governance challenges as economic uncertainty, globalisation, digitisation, and a more complex regulatory environment continue to reshape the business and risk environment" (KPMG, 2013).

\footnotetext{
13 Available at http://www.kpmg.com/cn/en/issuesandinsights/articlespublications/newsletters/china-boardroom-update/pages/c hina-boardroom-update-1302-01-audit-committee-priorities.aspx
} 
Acknowledgements: First we would like to thank the editor for his assistance and the two anonymous reviewers for their comments and guidance. We would also like to thank Lawrence Gordon, Ferdinand Gul, Tom Smith, Stephen Cox, David Tan, the participants at the 2009 Asian Finance Association International Conference, Brisbane Australia and the participants at the 2009 Accounting and Finance Association of Australia and New Zealand Conference, Adelaide Australia for their helpful comments. 


\begin{tabular}{|c|c|c|}
\hline \multicolumn{3}{|c|}{ Audit Committee Requirements } \\
\hline & $\begin{array}{l}\text { Hong Kong Exchanges and Clearing } \\
\text { Limited (HKEX), 2008 } \\
\text { http://www.hkex.com.hk/eng/exchange/corpgov/cgstru } \\
\text { cture/key_principles_ac.htm }\end{array}$ & $\begin{array}{l}\text { China Securities } \\
\text { Regulatory Commission } \\
\text { (CSRC), 2001 } \\
\text { http://www.ecgi.org/codes/documents/ } \\
\text { code_en.pdf }\end{array}$ \\
\hline Composition & $\begin{array}{l}\text { It consists of } 5 \text { independent non-executive } \\
\text { directors. They must be either qualified } \\
\text { accountants or professionals with extensive } \\
\text { experience in financial management. }\end{array}$ & $\begin{array}{l}\text { The firm may establish an audit } \\
\text { committee. Composed solely of } \\
\text { directors. Chaired by an } \\
\text { independent director. Consist of } \\
\text { a majority of independent } \\
\text { directors. At least one } \\
\text { independent director from the } \\
\text { audit committee shall be an } \\
\text { accounting professional }\end{array}$ \\
\hline $\begin{array}{l}\text { Major roles } \\
\text { and functions }\end{array}$ & $\begin{array}{l}\text { - To serve as a focal point for } \\
\text { communication between the Directors, } \\
\text { external auditors and internal auditors } \\
\text { - To assist the Board in fulfilling its } \\
\text { responsibility by providing an independent } \\
\text { review and supervision of financial } \\
\text { reporting, and monitoring and reviewing } \\
\text { the effectiveness of the Group's internal } \\
\text { controls (including the adequacy of } \\
\text { resources, qualifications and experience of } \\
\text { staff of the Group's accounting and } \\
\text { financial reporting function, and their } \\
\text { training programmes and budget) and the } \\
\text { adequacy of the external and internal } \\
\text { audits } \\
\text { - To review the appointment of external } \\
\text { auditors on an annual basis ensure } \\
\text { continuing auditors independence. } \\
\text { - To develop and monitor the applications of } \\
\text { the policies on the engagement of the } \\
\text { external auditors to perform non-audit } \\
\text { services (other than tax-related } \\
\text { services) and the hiring of the employees } \\
\text { or formal employees of the external } \\
\text { auditors. }\end{array}$ & $\begin{array}{l}\text { - To recommend the } \\
\text { engagement or replacement } \\
\text { of the company's external } \\
\text { auditing institutions } \\
\text { - To review the internal audit } \\
\text { system and its execution } \\
\text { - To oversee the interaction } \\
\text { between the company's } \\
\text { internal and external auditing } \\
\text { institutions } \\
\text { - To inspect the company's } \\
\text { financial information and its } \\
\text { disclosure } \\
\text { - To monitor the company's } \\
\text { internal control system. }\end{array}$ \\
\hline $\begin{array}{l}\text { Operating } \\
\text { mode }\end{array}$ & $\begin{array}{l}\text { At least } 4 \text { times a year with additional } \\
\text { meetings as the work of the Audit Committee } \\
\text { demands }\end{array}$ & Not provided \\
\hline $\begin{array}{l}\text { Audit } \\
\text { Committee } \\
\text { Report }\end{array}$ & $\begin{array}{l}\text { The work of the Audit Committee during each } \\
\text { financial year is summarized in the Audit } \\
\text { Committee Report contained in the annual } \\
\text { report }\end{array}$ & Not provided \\
\hline
\end{tabular}




\section{References}

Abbott, L.J., Parker, S., \& Peters, G. F. (2004). Audit committee characteristics and restatements. Auditing: A Journal of Practice and Theory, 23(1), 69-87.

Allen, F., Qian, J., \& Qian, M. (2005). Law, finance, and economic growth in China. Journal of Financial Economics, 77, 57-116.

Bartov, E., Gul, F.A., \& Tsui, J.S.L. (2000). Discretionary accruals models and audit qualifications. Journal of Accounting and Economics, 30(3), 421-452.

Becker, C.L., DeFond, M.L., Jiambalvo, J. \& Subramanyam, K.R. (1998). The effect of audit quality on earnings management. Contemporary Accounting Research, 15(1), 1-24.

Bédard, J., Chtourou, S.M. \& Courteau, L. (2004). The effect of audit committee expertise, independence, and activity on aggressive earnings management. Auditing: A Journal of Practice and Theory, 23(2), 13-35.

Butler, M., Leone, A.J. \& Willenborg, M. (2004). An empirical analysis of auditor reporting and its association with abnormal accruals. Journal of Accounting and Economics, 37(2), $139-165$.

Carcello, J.V., Hollingsworth, C.W., Klein, A. \& Neal, T.L. (2006). Audit committee financial expertise, competing corporate governance mechanisms, and earnings management. SSRN Working Paper: http://ssrn.com/abstract=887512.

Chan, K.H., Lin, K.Z., and Wang, R.R. (2012). Government ownership, accounting-based regulations, and the pursuit of favorable audit opinions: Evidence from China. Auditing: A Journal of Practice \& Theory, 31(4), 47-64.

Cheung, Y.L., Jiang, P., Limpaphayom, P. \& Lu, T. (2008). Does corporate governance matter in China? China Economic Review, 19, 460-479.

Chen, X., Lee, C.W.J. \& Li, J. (2008). Government assisted earnings management in China. Journal of Accounting and Public Policy, 27(3), 262-274.

Chi, W., \& Zhang, H. (2010). Are stronger executive incentives associated with cross-listing? Evidence from China. China Economic Review, 21(1), 150-160.

China Securities Regulatory Commission (CSRC). (2001). Accessed 22 August 2008 via http://www.ecgi.org/codes/documents/code_en.pdf.

Claessens, S., Djankov, S., Fan, J.P.H., \& Lang, L.P.H. (2002). Disentangling the incentive and entrenchment effects of large shareholdings. The Journal of Finance, 57(6), 2741-2771.

DeFond, M.L. \& Jiambalvo, J. (1994). Debt covenant violation and manipulation of accruals. Journal of Accounting \& Economics, 17(1-2), 145-176. 
DeZoort, F.T., Hermanson, D.R., Archambeault, D.S. \& Reed, S.A. (2002). Audit committee effectiveness: A synthesis of the empirical audit committee literature. Journal of Accounting Literature, 21, 38-75.

Dhaliwal, D.S., Naiker, V. \& Navissi, F. (2006). The Association Between Accruals Quality and the Characteristics of Accounting Experts and Mix of Expertise on Audit Committees. Contemporary Accounting Research, 27(3), 787-827.

Dinardo, J., \& Johnston, J. (1997). Econometrics, Fourth Edition, McGraw-Hill

Ding, Y., Zhang, H. \& Zhang, J. (2007). Private vs. state ownership and earnings management: Evidence from Chinese listed companies. Corporate Governance: An International Review, 15(2), 223-238.

Fama, E.F. \& Jensen, M.C. (1983). Separation of ownership and control. The Journal of Law and Economics, 26 (2), 301-325.

Fan, J.P.H., Wong, T.J. \& Zhang, T. (2007). Politically connected CEOs, corporate governance, and post-IPO performance of China's newly partially privatized firms. Journal of Financial Economics, 84 (2), 330-357.

Firth, M., Fung, P.M.Y., \& Rui, O. M. (2007). Ownership, two-tier board structure, and the informativeness of earnings: Evidence from China. Journal of Accounting and Public Policy, 26(4), 463-496.

Firth, M., Malatesta, P.H., Xin, Q., \& Xu, L. (2012). Corporate investment, government control, and financing channels: Evidence from China's listed companies. Journal of Corporate Finance, 18, 433-450.

Firth, M., Gong, S.X., \& Shan, L. (2013) Cost of government and firm value. Journal of Corporate Finance, 21,136-152.

Gao, S., Gao, G. \& Zhang T. (2008). Corporate governance reform and firm performance: Evidence from China in M. Tsamenyi \& S. Uddin (Eds.), Corporate Governance in Less Developed and Emerging Economies, Emerald Group Publishing Limited, Bingley, 8,189-209.

Gow, I.D., Ormazabal, G. \& Taylor, D.J. (2010). Correcting for cross-sectional and time-series dependence in accounting research. The Accounting Review, 85(2), 483-512.

He, J., Mao, X., Rui, O.M., \& Zha, X. (2013) Business groups in China. Journal of Corporate Finance, 22, 166-192.

Healy, P.M. \& Wahlen J.M. (1999) A Review of the Earnings Management Literature and Its Implications for Standard Setting. Accounting Horizons, 13(4), 365-383. 
Heckman, J.J. (1976). The common structure of statistical models of truncation, sample selection and limited dependent variables and a simple estimator for such models. Annals of Economic and Social Measurement, 5(4), 475-492.

Hong Kong Exchanges and Clearing Limited (HKEX), (2008). Accessed 22 August 2008 via http://www.hkex.com.hk/eng/exchange/corpgov/cgstructure/key_principles_ac.htm)

Hutchinson, M., \& Leung, S. (2007). An investigation of factors influencing the association between top management ownership and earnings management. Journal of Contemporary Accounting and Economics, 3(2), 130-153.

Jaggi, B. \& Leung, S. (2007). Impact of family dominance on monitoring of earnings management by audit committees: evidence from Hong Kong. Journal of International Accounting Auditing \& Taxation, 16(1), 27-50.

Jia, J. \& Sun, Q. (2005). Privatization through an overseas listing: Evidence from China's H-Share firms. Financial Management, 34(3), 5-30.

Jog, V., Zhu, P.C., \& Dutta, S. (2010). Impact of restricted voting share structure on firm value and performance. Corporate Governance: An International Review, 18(5), 415 437.

Jones, J. (1991). Earnings management during import relief investigations. Journal of Accounting Research, 29 (2), 193-228.

Karolyi, G. A. (2010). Corporate governance, agency problems, and international cross-listings: A defence of the bonding hypothesis. Working paper, Cornell University.

Kinney, W.R.Jr., \& McDaniel, L.S. (1989). Characteristics of firms correcting previously reported quarterly earnings. Journal of Accounting and Economics, 11(1), 71-93.

Klein, A. (2002). Audit committee, board of director characteristics, and earnings management. Journal of Accounting and Economics, 33 (3), 375-400.

KPMG China (2013). Accessed 1 September 2013 via

http://www.kpmg.com/cn/en/issuesandinsights/articlespublications/newsletters/china-boardro om-update/pages/china-boardroom-update-1302-01-audit-committee-priorities.aspx

Krishnan, G.V. (2003). Does Big 6 auditor industry expertise constrain earnings management? Accounting Horizons, 17,1-16.

Krishnan, G.V., \& Parsons, L.M. (2008). Getting to the bottom line: an exploration of gender and earnings quality. Journal of Business Ethics, 78(1-2), 65-76.

Lai, L. \& Tam, H. (2007). Independent directors and the propensity to smooth earnings: A study of corporate governance in China. The Business Review, Cambridge, 7(1), 328-335.

Lennox, C.S., Francis, J.R \& Wang, Z. (2012). Selection Models in Accounting Research. The Accounting Review, 87(2), 589-616. 
Li, Y., Sun, Y. \& Liu, Y. (2006). An empirical study of SOEs market orientation in transitional China. Asia Pacific Journal of Management, 23(1), 93-113.

Lin, J.W., Li, J.F. \& Yang, S.Y. (2006). The effect of audit committee performance on earnings quality. Managerial Auditing Journal, 21(9), 921-933.

Lin, Z.J., Xiao, J.Z. \& Tang, Q. (2008). The roles, responsibilities and characteristics of audit committee in China. Accounting, Auditing and Accountability Journal, 21(5), 721-751.

Lin, Z., \& Liu, M. (2009). The determinants of auditor switch from the perspective of corporate governance in China. Corporate Governance: An International Review, 17, 476-491.

Liu, Q. \& Lu, Z. (2007). Corporate governance and earnings management in Chinese listed companies: A tunnelling perspective. Journal of Corporate Finance, 13(5), 881-906.

Liu, L. \& Ma, X. (2008). Audit committee and audit quality: empirical evidence from Chinese A-share market. Accounting Research (Chinese Version), 7, 84-90.

Lo, A.W.Y., Wong, R.M.K., \& Firth, M. (2010). Can corporate governance deter management from manipulating earnings? Evidence from related-party sales transactions in China. Journal of Corporate Finance, 16, 225-235.

Petersen, M. (2009). Estimating standard errors in financial panel data sets: comparing approaches. The Review of Financial Studies, 22(1), 435-480.

Pistor, K. \& Xu, C. (2005). Governing stock markets in transition economies: Lessons from China, American Law and Economic Review, 7 (1),184-210.

Piotroski, J.D., Wong, T.J., \& Zhang, T. (2011). Political Incentives to Suppress Negative Information: Evidence from Chinese Listed Firms, working paper, Stanford University.

Piotroski, J. D. \& Wong, T.J. (2011). Capitalizing China: Institutions and information environment of Chinese listed firms (April 2011). NBER Book Chapter. Available at SSRN: http://ssrn.com/abstract=1876920

Smith, C.W., \& Stulz, R.M. (1985). The determinants of firms' hedging policies. Journal of Financial and Quantitative Analysis, 20(4), 391-405.

Smith, C.W., \& Watts, R.L. (1992). The investment opportunity set and corporate financing, dividend, and compensation policies. Journal of Financial Economics, 32(3), 263-292.

Sun, L.X. \& Tobin, D. (2005). International listing as a mechanism of commitment to more credible corporate governance practices: The case of the Bank of China (Hong Kong). Corporate Governance: An International Review, 13(1), 81-91.

Sweeney, A.P. (1994). Debt-covenant violations and managers' accounting responses. Journal of Accounting and Economics, 17(3), 281-308. 
Wei, G. (2007). Ownership structure, corporate governance and company performance in China. Asia Pacific Business Review, 13(4),519-545

Xie, B., Davidson, W.N. \& DaDalt, P.J. (2003). Earnings management and corporate governance: The role of the board and the audit committee. Journal of Corporate Finance, 9(3), 295-316.

Xu, L.C., Zhu, T. \& Lin, Y. (2005). Politician control, agency problems and ownership reform. Evidence from China. The Economics of Transition, 13 (1), 1-24.

Yang, J.S. \& Krishnan, J. (2005). Audit committees and quarterly earnings management. International Journal of Auditing, 9(3), 201-219.

Zheng, X. \& Liu, G. (2008). The investigation on audit committee's effectiveness from the perspective of earnings management. Communication of Finance and Accounting (Chinese Version), 8, 98-118. 
Table 1: Variables information

\section{Dependent Variable:}

\begin{tabular}{|l|l}
$\boldsymbol{A B A C}$ & Abnormal accruals are the residuals from running the regression of equation (1).
\end{tabular}

\section{Independent Variables:}

\begin{tabular}{|c|c|}
\hline HKCL & $\begin{array}{l}\text { Dummy variable } 1 \text { if a Chinese listed firm is cross listed on the Hong Kong Stock } \\
\text { Exchange, and } 0 \text { if listed in mainland China only. }\end{array}$ \\
\hline GOV & $\begin{array}{l}\text { Dummy variable } 1 \text { if an audit committee includes government officials as } \\
\text { independent members; 0: otherwise. }\end{array}$ \\
\hline$A C$ & Dummy variable 1 if a listed firm has an audit committee; 0 : otherwise. \\
\hline$A C I N D$ & $\begin{array}{l}\text { Number of independent directors divided by total number of directors on the audit } \\
\text { committee. }\end{array}$ \\
\hline$A C E X P$ & $\begin{array}{l}\text { A factor score of independent audit committee members' accounting, financial and } \\
\text { industry experience is created by using principal components' factor analysis and } \\
\text { scaled by audit committee size. }\end{array}$ \\
\hline
\end{tabular}

Control Variables:

\begin{tabular}{|l|l|}
\hline STATE & $\begin{array}{l}\text { Dummy variable } 1 \text { if the proportion of State shareholdings to total issued shares is } \\
\text { greater than or equal to the median; 0 otherwise. }\end{array}$ \\
\hline BIG4 & Dummy variable 1 if the firm is audited by a Big4 accounting firm; 0 otherwise. \\
\hline LEV & Leverage is (Long-term debt + Debt in current liabilities) / Total assets. \\
\hline ROEDUM & Dummy variable 1 for ROE less than zero; 0 otherwise. \\
\hline MBVA & $\begin{array}{l}\text { Book to market value is calculated as market capitalisation divided by the book } \\
\text { value of assets. }\end{array}$ \\
\hline LNAT & $\begin{array}{l}\text { Firm size is measured as total assets in million RMB. A natural logarithmic } \\
\text { transformation is performed to normalise data. }\end{array}$ \\
\hline YEAR & Dummy variable for each year 2004, 2005, 2006, 2007 and 2008. \\
\hline MATERIAL & Dummy variable 1 if firms in material sector ; 0 otherwise. \\
\hline INDUSTRIAL & Dummy variable 1 if firms in industrial sector ; 0 otherwise. \\
\hline
\end{tabular}


Table 2: Sampling details (All firms including CL and DLO firms)

\begin{tabular}{|l|c||c|c|}
\hline \multicolumn{1}{|c|}{ Industry } & No. of observations & Year observed & No. of firms \\
\hline Consumer Staples & 4 & 2004 & 42 \\
Material & 120 & 2005 & 43 \\
Consumer Discretionary & 38 & 2006 & 56 \\
Industrial & 186 & 2007 & 184 \\
Health Care & 8 & 2008 & 83 \\
Utilities & 26 & & \\
I.T. & 10 & & \\
Financials & 16 & & 408 \\
\hline Total & 408 & & \\
\hline
\end{tabular}


Table 3: Descriptive statistics and paired matched sample comparison (t-test)

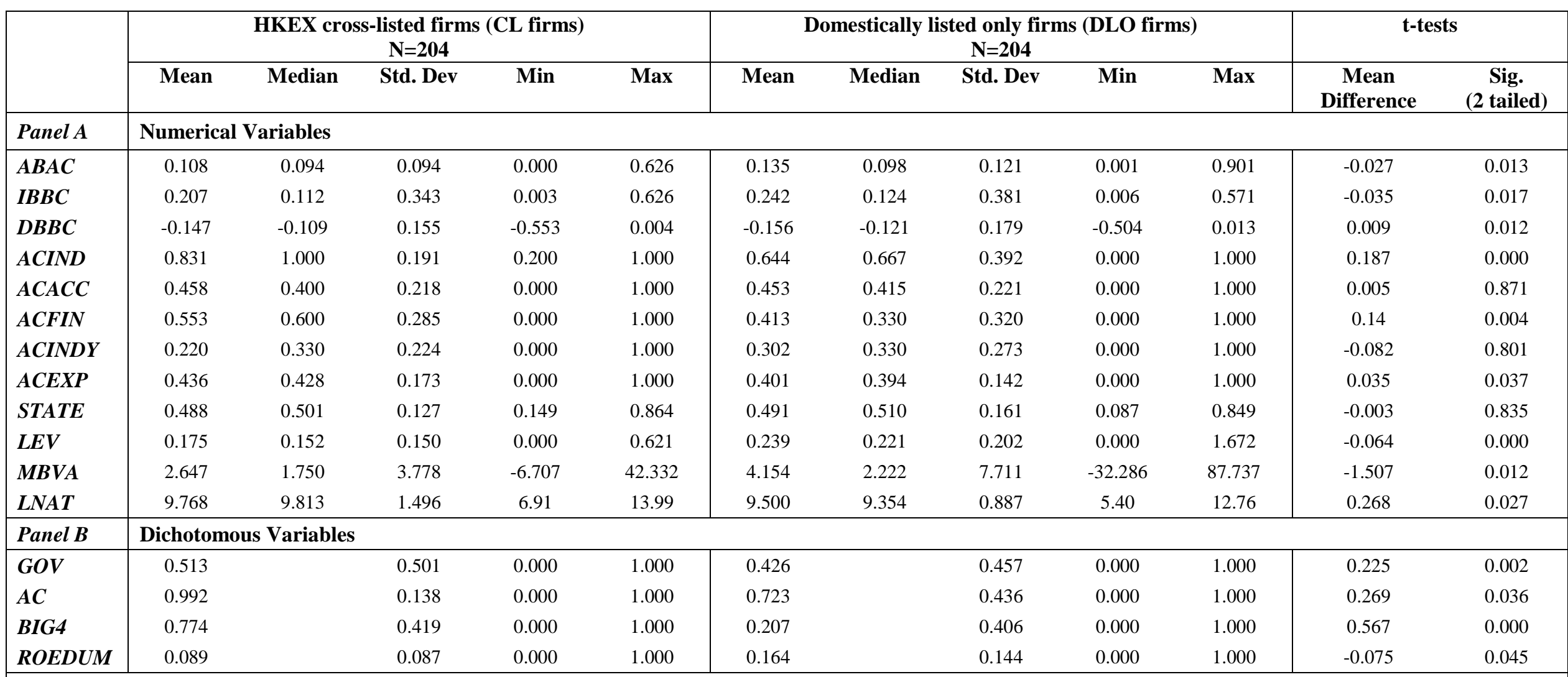

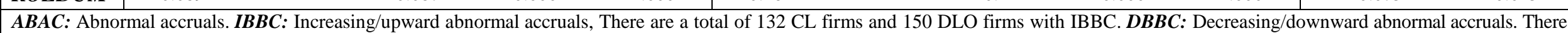

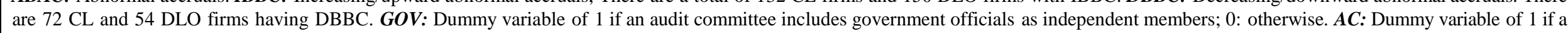

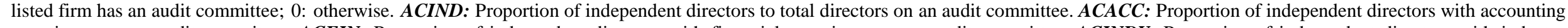

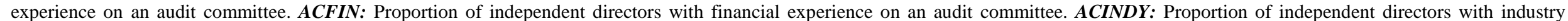

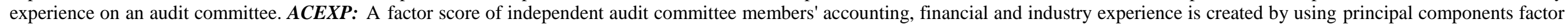

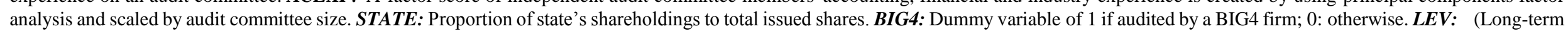
debt + debt in current liabilities) / total assets. ROEDUM: Dummy variable 1 for ROE less than zero; 0 otherwise. MBVA: Market to Book value of assets. LNAT: Log of total assets in million RMB. 
Table 4: Pearson correlation Coefficients $(\mathrm{N}=408)$

\begin{tabular}{|c|c|c|c|c|c|c|c|c|c|c|c|c|c|c|}
\hline & & 1 & 2 & 3 & 4 & 5 & 6 & 7 & 8 & 9 & 10 & 11 & 12 & 13 \\
\hline 1 & $A B A C$ & 1 & & & & & & & & & & & & \\
\hline 2 & $H K C L$ & $-0.122 * *$ & 1 & & & & & & & & & & & \\
\hline 3 & GOV & $0.025^{*}$ & -0.115 & 1 & & & & & & & & & & \\
\hline 4 & $A C$ & -1.823 & 1.358 & -1.480 & 1 & & & & & & & & & \\
\hline 5 & $A C I N D$ & $-0.326^{* *}$ & $0.286^{*}$ & -0.015 & 0.827 & 1 & & & & & & & & \\
\hline 6 & ACEXP & -0.272 & 0.027 & -0.259 & 0.936 & $0.392 * *$ & 1 & & & & & & & \\
\hline 7 & STATE & $0.018^{*}$ & -0.011 & 0.004 & -0.753 & $-0.036^{* *}$ & -0.042 & 1 & & & & & & \\
\hline 8 & BIG4 & -0.093 & $0.567 * *$ & -0.031 & 0.639 & $0.438^{* *}$ & $0.037^{*}$ & -0.042 & 1 & & & & & \\
\hline 9 & $L E V$ & $-0.041^{*}$ & $0.177 * *$ & $-0.012^{*}$ & 0.816 & $0.077^{*}$ & 0.024 & $-0.142 * *$ & 0.048 & 1 & & & & \\
\hline 10 & ROEDUM & $0.110^{* *}$ & -0.085 & 0.053 & -0.975 & $-0.051 * *$ & $-0.282 * *$ & 0.001 & $-0.162 * *$ & -0.044 & 1 & & & \\
\hline 11 & $M B V A$ & $0.006^{*}$ & $-0.123^{*}$ & 0.002 & -1.072 & -0.402 & $-0.038^{*}$ & 0.079 & -0.032 & 0.170 & 0.047 & 1 & & \\
\hline 12 & $L N T A$ & -0.008 & $0.108^{*}$ & -0.003 & 1.376 & $0.262 * *$ & $0.127 * *$ & $-0.408^{* *}$ & 0.083 & -0.054 & -0.042 & $-0.085 * *$ & 1 & \\
\hline 13 & MATERIAL & 0.062 & -0.001 & 0.028 & -1.123 & -0.021 & -0.052 & $0.107^{*}$ & -0.022 & $0.105^{*}$ & 0.037 & $-0.171 * *$ & $-0.063 * *$ & 1 \\
\hline 14 & INDUSTRIAL & -0.041 & $0.005^{* *}$ & $-0.018^{*}$ & 0.994 & 0.083 & $0.037^{*}$ & $-0.151 * *$ & $0.147 * *$ & -0.052 & -0.031 & $0.168 * *$ & $-0.595 * *$ & -0.012 \\
\hline \multicolumn{15}{|c|}{$\begin{array}{l}\text { ABAC: Abnormal accruals. HKCL: Dummy variable } 1 \text { if the Chinese listed firm is cross listed on the Hong Kong Stock Exchange, and } 0 \text { if listed in mainland China only. } \\
\text { GOV: Dummy variable of } 1 \text { if the audit committee includes government officials as independent members; 0: otherwise. AC: Dummy variable of } 1 \text { if a listed firm has an audit } \\
\text { committee; 0: otherwise. ACIND: Proportion of independent directors to total directors on an audit committee. ACEXP: A factor score of independent audit committee } \\
\text { members' accounting, financial and industry experience is created by using principal components factor analysis and scaled by audit committee size. STATE: Proportion of } \\
\text { state's shareholdings to total issued shares. BIG4: Dummy variable of } 1 \text { if audited by a BIG4 firm; 0: otherwise. } \boldsymbol{L E V :} \text { (Long-term debt + debt in current liabilities) / total } \\
\text { assets. ROEDUM: Dummy variable } 1 \text { for ROE less than zero; } 0 \text { otherwise. MBVA: Market to Book value of assets. } \boldsymbol{L N A T} \text { : Log of total assets in million RMB. MATERIAL: } \\
\text { Dummy variable } 1 \text { if firms in material sector; } 0 \text { otherwise. INDUSTRIAL: Dummy variable } 1 \text { if firms in industrial sector; } 0 \text { otherwise. } \\
\text { *,**and*** indicate significance at the } 10 \%, 5 \% \text {, and } 1 \% \text { levels. }\end{array}$} \\
\hline
\end{tabular}


Table 5: Heckman selection regression with cluster robustness for testing impact of cross-listing on audit committee effectiveness $(N=408)$

\begin{tabular}{|c|c|c|c|c|c|}
\hline \multicolumn{2}{|c|}{ Dep. Variable: $A B A C$} & \multicolumn{4}{|c|}{ Impact of cross-listing on audit committee effectiveness (H1) } \\
\hline & & & $\begin{array}{c}\text { Step 1 } \\
\text { Panel A }\end{array}$ & $\begin{array}{c}\text { Step 2 } \\
\text { Panel B }\end{array}$ & $\begin{array}{c}\text { Step 3 } \\
\text { Panel C }\end{array}$ \\
\hline \multicolumn{2}{|c|}{ Prediction } & & \multicolumn{3}{|c|}{ All firms (CL firms and DLO firms) } \\
\hline (Constant) & & $0.123\left(1.298^{* *}\right)$ & $0.152(2.723 * * *)$ & $0.156(2.627 * * *)$ & $0.214(1.762 *)$ \\
\hline$A C$ & - & $-0.183(-0.042)$ & $-0.482(-0.028)$ & $-0.052(-0.072)$ & $0.285(0.005)$ \\
\hline HKCL & - & & $-0.094(-1.636 *)$ & $-0.072\left(-1.346^{*}\right)$ & $0.034(1.829 * *)$ \\
\hline ACIND & - & & & $-0.19(-2.352 * *)$ & $0.084(1.782 * *)$ \\
\hline ACEXP & - & & & $-0.012(-1.692 *)$ & $0.174(1.963 * *)$ \\
\hline$H K C L * A C I N D$ & $?$ & & & & $-0.082(-1.462 *)$ \\
\hline$H K C L * A C E X P$ & $?$ & & & & $-0.161(-2.212 * *)$ \\
\hline STATE & $?$ & $0.142\left(2.686^{* * *}\right)$ & $0.173(2.629 * * *)$ & $0.162\left(2.516^{* * *}\right)$ & $0.165\left(2.415^{* *}\right)$ \\
\hline$M I L L S$ & $?$ & $0.557(0.874)$ & $0.478(0.769)$ & $0.579(0.853)$ & $0.374(0.481)$ \\
\hline BIG4 & - & $-0.321(-2.652 * * *)$ & $-0.062(-1.662 *)$ & $-0.041(-1.827 *)$ & $-0.362(-2.624 * * *)$ \\
\hline$L E V$ & + & $-0.057(-2.392 * *)$ & $-0.385(-5.632 * * *)$ & $-0.303(-5.847 * * *)$ & $-0.075(-2.392 * *)$ \\
\hline ROEDUM & + & $0.336\left(2.523^{* *}\right)$ & $0.034\left(2.718^{* *}\right)$ & $0.029\left(2.926^{* * *}\right)$ & $0.017(2.324 * *)$ \\
\hline$M B V A$ & + & $0.042(0.859)$ & $0.012(-0.573)$ & $0.024(-0.625)$ & $0.084(0.925)$ \\
\hline$L N A T$ & - & $-0.042(-0.485)$ & $-0.025(-0.416)$ & $-0.014(-0.476)$ & $-0.035(-0.163)$ \\
\hline YEAR & $?$ & Included & Included & Included & Included \\
\hline MATERIAL & $?$ & $0.002(0.534)$ & $0.012(0.247)$ & $0.004(0.151)$ & $0.005(0.427)$ \\
\hline INDUSTRIAL & $?$ & $-0.024(-0.688)$ & $-0.048(-1.521 *)$ & $-0.029(-1.528 *)$ & $-0.014(-0.583)$ \\
\hline Adjusted $R^{2}$ & & 0.046 & 0.054 & 0.064 & 0.066 \\
\hline $\boldsymbol{F}$ & & $3.376^{* * *}$ & $3.478^{* * * *}$ & $3.628^{* * *}$ & $2.854 * * *$ \\
\hline \multicolumn{6}{|c|}{$\begin{array}{l}\text { ABAC: Abnormal accruals. HKCL: Dummy variable } 1 \text { if the Chinese listed firm is cross listed on the Hong Kong Stock } \\
\text { Exchange, and } 0 \text { if listed in mainland China only. AC: Dummy variable of } 1 \text { if a listed firm has an audit committee; } 0: \\
\text { otherwise. ACIND: Proportion of independent directors to total directors on the audit committee. ACEXP: A factor score of } \\
\text { independent audit committee members' accounting, financial and industry experience is created by using principal } \\
\text { components factor analysis and scaled by audit committee size. STATE: Proportion of state's shareholdings to total issued } \\
\text { shares. MILLS: The inverse Mills ratio results from the first-stage Probit regression. BIG4: Dummy variable of } 1 \text { if } \\
\text { audited by a BIG4 firm; 0: otherwise. LEV: (Long-term debt + debt in current liabilities) / total assets. ROEDUM: } \\
\text { Dummy variable } 1 \text { for ROE less than zero; } 0 \text { otherwise. MBVA: Market to Book value of assets. LNAT: Log of } \\
\text { total assets in million RMB. MATERIAL: Dummy variable } 1 \text { if firms in material sector; } 0 \text { otherwise. INDUSTRIAL: } \\
\text { Dummy variable } 1 \text { if firms in industrial sector; } 0 \text { otherwise. } \\
*, * * \text { and } * * * \text { indicate significance at the } 10 \%, 5 \% \text {, and } 1 \% \text { levels. }\end{array}$} \\
\hline
\end{tabular}


Table 6: Heckman selection regression with cluster robustness for testing impact of government officials on audit committee effectiveness

\begin{tabular}{|c|c|c|c|c|c|}
\hline \multicolumn{2}{|c|}{ Dep. Variable: $A B A C$} & \multicolumn{4}{|c|}{ Impact of government officials on audit committee effectiveness (H2) } \\
\hline \multicolumn{2}{|c|}{ Prediction } & $\begin{array}{c}\text { Panel A } \\
\text { (DLO firms) }\end{array}$ & $\begin{array}{c}\text { Panel B } \\
\text { (CL firms) }\end{array}$ & $\begin{array}{c}\text { Panel C } \\
\text { (DLO firms) }\end{array}$ & $\begin{array}{c}\text { Panel D } \\
\text { (CL firms) }\end{array}$ \\
\hline (Constant) & & $0.151(1.325 *)$ & $0.143(1.231 *)$ & $0.145(1.534 *)$ & $0.149(2.874 * * *)$ \\
\hline GOV & - & $0.035(1.374 *)$ & $0.031(1.284 *)$ & $-0.073(-2.026 * *)$ & $-0.036(-1.692 * *)$ \\
\hline ACIND & - & $-0.219(-1.632 *)$ & $-0.109(-1.873 * *)$ & $0.235\left(2.291^{* * *}\right)$ & $0.169(1.842 * *)$ \\
\hline ACEXP & - & $0.075(1.192)$ & $-0.162(-1.693 * *)$ & $0.218(2.547 * * *)$ & $0.165\left(1.825^{* *}\right)$ \\
\hline$G O V * A C I N D$ & $?$ & & & $0.245(2.372 * *)$ & $0.045(1.472 *)$ \\
\hline$G O V * A C E X P$ & $?$ & & & $0.282(2.932 * * *)$ & $0.266(2.743 * * *)$ \\
\hline MILLS & ? & $0.562(0.527)$ & $0.437(0.689)$ & $0.507(0.628)$ & $0.609(0.923)$ \\
\hline STATE & $?$ & $0.183(2.152 * *)$ & $0.165(2.351 * *)$ & $0.151\left(1.843^{*}\right)$ & $0.267(1.397 *)$ \\
\hline BIG4 & - & $-0.082(-1.838 * *)$ & $-0.078(-1.712 * *)$ & $-0.231(-2.172 * *)$ & $-0.242(-1.382 *)$ \\
\hline$L E V$ & + & $-0.094(-2.315 * *)$ & $-0.082\left(-2.371^{* *}\right)$ & $-0.071\left(-2.286^{* *}\right)$ & $-0.032-1.681 *)$ \\
\hline ROEDUM & + & $0.019(2.747 * *)$ & $0.015(2.374 * *)$ & $0.075(2.199 * *)$ & $0.029(1.964 * *)$ \\
\hline$M B V A$ & + & $0.072(0.974)$ & $0.067(0.921)$ & $0.157(1.746 *)$ & $0.131\left(1.411^{*}\right)$ \\
\hline LNAT & - & $-0.032(-0.306)$ & $-0.022(-0.226)$ & $-0.015(-0.145)$ & $-0.078(-0.071)$ \\
\hline YEAR & ? & Included & Included & Included & Included \\
\hline MATERIAL & ? & $0.034(0.562)$ & $0.007(0.334)$ & $0.019(0.582)$ & $0.062(0.494)$ \\
\hline INDUSTRIAL & $?$ & $-0.008(-0.635)$ & $-0.012(-0.713)$ & $-0.447(-0.612)$ & $-0.564(-0.464)$ \\
\hline Adjusted $R^{2}$ & & 0.086 & 0.075 & 0.062 & 0.053 \\
\hline$F$ & & $3.581 * *$ & $3.225^{* *}$ & $3.518 * * *$ & $3.183 * * *$ \\
\hline $\mathbf{N}$ & & 204 & 204 & 204 & 204 \\
\hline \multicolumn{6}{|c|}{$\begin{array}{l}\text { ABAC: Abnormal accruals. GOV: Dummy variable of } 1 \text { if an audit committee includes government officials as } \\
\text { independent members; 0: otherwise. ACIND: Proportion of independent directors to total directors on an audit committee. } \\
\text { ACEXP: A factor score of independent audit committee members' accounting, financial and industry experience is created } \\
\text { by using principal components factor analysis and scaled by audit committee size. MILLS: The inverse Mills ratio results } \\
\text { from the first-stage Probit regression. STATE: Proportion of state's shareholdings to total issued shares. BIG4: Dummy } \\
\text { variable of } 1 \text { if audited by a BIG4 firm; 0: otherwise. } \mathbf{L E V} \text { : (Long-term debt + debt in current liabilities) / total assets. } \\
\text { ROEDUM: Dummy variable } 1 \text { for ROE less than zero; } 0 \text { otherwise. MBVA: Market to Book value of assets. } \\
\text { LNAT: Log of total assets in million RMB. MATERIAL: Dummy variable } 1 \text { if firms in material sector; } 0 \text { otherwise. } \\
\text { INDUSTRIAL: Dummy variable } 1 \text { if firms in industrial sector; } 0 \text { otherwise. } \\
\text { ***and*** indicate significance at the } 10 \%, 5 \% \text {, and } 1 \% \text { levels. }\end{array}$} \\
\hline
\end{tabular}


Table 7: OLS regression with cluster robustness for testing impact of cross-listing on audit committee effectiveness using IBBC and DBBC (sensitivity tests).

\begin{tabular}{|c|c|c|c|c|c|c|c|}
\hline \multicolumn{2}{|l|}{ Dep.Variables } & \multicolumn{3}{|r|}{ IBBC } & \multicolumn{3}{|r|}{ DBBC } \\
\hline \multicolumn{2}{|c|}{ Prediction } & Panel A & Panel B & Panel C & Panel D & Panel E & Panel F \\
\hline (Constant) & & $0.172\left(1.879^{* *}\right)$ & $0.115\left(1.247^{*}\right)$ & $0.147\left(1.730^{* *}\right)$ & $0.156\left(1.453^{*}\right)$ & $0.169\left(1.327^{*}\right)$ & $0.165\left(1.849^{*}\right)$ \\
\hline HKCL & - & $-0.164\left(-1.638^{*}\right)$ & $-0.174(-1.582 *)$ & $0.197(1.187 *)$ & $-0.064(-1.862 *)$ & $-0.051(-0.125)$ & $0.064(1.692 *)$ \\
\hline$A C$ & - & & $-1.339(-0.014)$ & $1.728(0.0172)$ & & $-1.064(-.006)$ & $1.037(0.092)$ \\
\hline ACIND & - & & $-1.175(-0.096)$ & $1.174(0.148)$ & & $-0.086(-1.724 *)$ & $0.075\left(1.408^{*}\right)$ \\
\hline ACEXP & - & & $-1.519(-1.472 *)$ & $1.568(1.472 * *)$ & & $-0.153\left(-1.527^{*}\right)$ & $0.128\left(1.674^{*}\right)$ \\
\hline$H K C L * A C I N D$ & $?$ & & & $-0.315\left(-2.731^{* *}\right)$ & & & $-0.065(-1.426 *)$ \\
\hline$H K C L^{*} A C E X P$ & $?$ & & & $-0.257(-0.636)$ & & & $-0.054(-0.879)$ \\
\hline \multicolumn{8}{|l|}{ Controls } \\
\hline STATE & $?$ & $0.734(0.739)$ & $0.162(0.722)$ & $0.151(0.624)$ & $0.061(0.548)$ & $0.073(0.878)$ & $0.074(0.861)$ \\
\hline BIG4 & - & $-0.325\left(-2.531^{* *}\right)$ & $-0.389(-2.074 * * *)$ & $-0.416(-2.264 * *)$ & $-0.197\left(-1.826^{*}\right)$ & $-0.270\left(-1.737^{*}\right)$ & $-0.258\left(-1.623^{*}\right)$ \\
\hline$L E V$ & + & $0.138\left(2.356^{* * *}\right)$ & $0.165\left(2.218^{* * *}\right)$ & $0.153(2.128 * *)$ & $0.142(2.252 *)$ & $0.162(2.149 * *)$ & $0.281\left(1.915^{* *}\right)$ \\
\hline ROEDUM & + & $0.041(2.579 * * *)$ & $0.367(2.537 * * *)$ & $0.325(1.553 * *)$ & $-0.053(-0.534)$ & $-0.091\left(-1.792^{*}\right.$ & $-0.032\left(-1.327^{*}\right)$ \\
\hline$M B V A$ & + & $0.221(0.738)$ & $0.147\left(1.611^{* *}\right)$ & $0.122(1.453 * *)$ & $-0.085\left(-1.581^{*}\right)$ & $-0.055(-1.914 *)$ & $-0.074(-1.362 *)$ \\
\hline LNAT & - & $0.079(0.586)$ & $0.069\left(1.735^{* *}\right)$ & $0.068(0.625)$ & $-0.041(-1.972 * *)$ & $-0.016\left(-2.143^{* *}\right)$ & $-0.025\left(-1.968^{* *}\right)$ \\
\hline$Y E A R$ & $?$ & Included & Included & Included & Included & Included & Included \\
\hline MATERIAL & $?$ & $-0.003(-0.724)$ & $-0.026(-0.273)$ & $-0.037(-0.145)$ & $-0.033(-0.278)$ & $-0.018(-0.094)$ & $-0.075(-0.067)$ \\
\hline INDUSTRIAL & $?$ & $-0.036(-0.871)$ & $-0.042(-0.353)$ & $-0.031(-0.662)$ & $-0.038(-0.245)$ & $-0.034(-1.033)$ & $-0.027(-0.731)$ \\
\hline Adjusted R2 & & 0.044 & 0.051 & 0.045 & 0.052 & 0.055 & 0.060 \\
\hline$F$ & & $2.932 * * *$ & $2.459 * * *$ & $2.257 * * *$ & $3.027^{* * *}$ & $3.346^{* * *}$ & $3.384 * * *$ \\
\hline $\mathbf{N}$ & & 282 & 282 & 282 & 126 & 126 & 126 \\
\hline \multicolumn{8}{|c|}{ 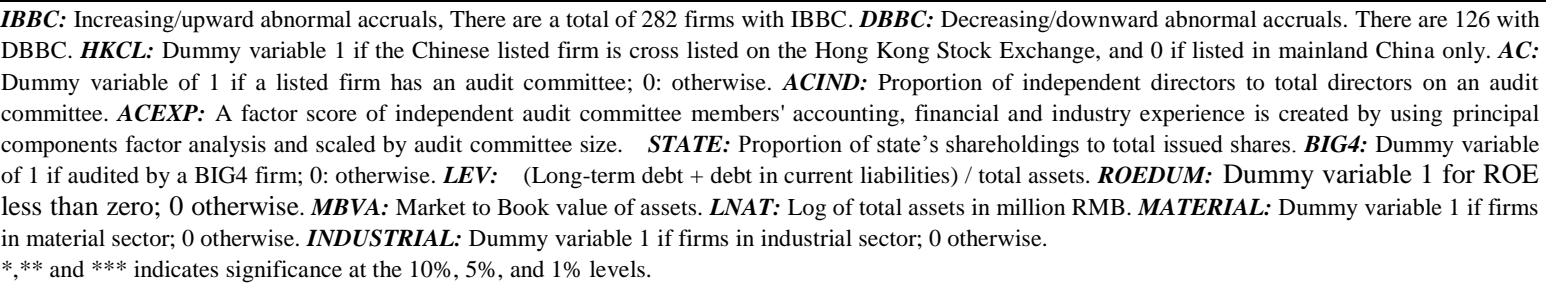 } \\
\hline
\end{tabular}


